\title{
Forthcoming events from the BDA
}

The events team at the British Dental Association have an exciting programme of seminars and conferences scheduled over the coming months. Anyone who attends a BDA event will find it an invaluable learning experience and a great opportunity to pick up verifiable CPD points. Here Tina Smith details the various launch events, conferences and repeats of some of the more popular seminars that will provide something of interest for all dental team members.

\section{Achieving high standards in infection control}

The infection control seminars have proved to be so popular that another series of dates has been added to meet demand. Relevant to the entire dental team, this seminar will help you ensure that you and your staff are protected, give you advice and guidance on maintaining high levels of infection control and help you learn practical lessons from case study examples.

Venues and dates:

The Village Hotel, Leeds - 17 October 2008

BDA, London - 27 February 2009

Belfry Hotel, Oxford - 26 June 2009

\section{BDA Hospitals Group Annual \\ Presidential and Scientific meeting}

The theme of this year's Hospitals Group Annual Presidential and Scientific meeting is 'Controversies, dilemmas and conundrums in clinical practice'. This event is open to all - you do not have to be a member of the Hospitals Group to attend.

The event will cover topics such as 'Antibiotic prophylaxis, infective endocarditis and dentistry - it was time for a rethink'; 'periodontitis and treatment impact on systemic health and development of disease'; 'Carious deciduous teeth; to restore or not to restore'; 'Face transplants: the French experience three years on'; 'Psychology in practice: its role in the care and rehabilitation of patients with disfiguring conditions'; and 'Stem cellbased dental implants'

Venue and date:

Magdalene College, Cambridge

- 25 to 26 September 2008

\section{BDA Community Dental Services Group Annual Presidential and \\ Scientific meeting}

Designed to appeal to all dentists with an interest in special care dentistry and community dentistry, this conference provides two days of informative and enlightening lectures by renowned speakers. Entitled 'Reaching out - when dental patients are the big issue', it is open to all. You do not have to be a member of the CDS Group to attend.

The clinical presentations on the first day explore three groups of patients who commonly rely on salaried services for their care: the homeless, drug users and dental phobics. On the second day various models by which dental schools are using outreach training to encourage students to adopt a patient-centred approach to dental care will be examined.

This year the event will be held in Matlock Bath, Derbyshire, a unique village which lies alongside the River Derwent. Delegates are encouraged to make a weekend of it and bring their partner or family.

Venue and date:

New Bath Hotel, Matlock Bath, Derbyshire

- 8 to 10 October 2008

\section{Preparing for retirement}

The BDA has been running these successful seminars for many years and they are proving to be as popular as ever. Experienced speakers will be giving delegates advice on financial planning, disposing of the practice, the NHS pension scheme and how to manage the lifestyle change retirement brings, along with other insightful presentations. For the first time the BDA will also be bringing this popular seminar to Scotland.

Venues and dates:

BDA, London - 31 October 2008

Westerwood Hotel, Glasgow

- 13 February 2009

Belfry Hotel, Oxford - 26 June 2009

\section{Setting up in practice}

If you are planning to set out on your own for the first time, buy into an existing practice or establish your own practice from scratch, this seminar is a must. The one-day course takes you through all the practical aspects of setting up in practice as well as business planning and management. Topics covered include up-to-the-minute legislation on employment of staff, health and safety in the dental practice and an interactive panel session giving you the opportunity to ask any question relating to your needs.

Venues and dates:

BDA, London - 12 December 2008

Menzies Hotel, Glasgow - 13 March 2009

Novotel Birmingham Centre, Birmingham

- 17 July 2009

\section{Career opportunities in UK dentistry}

The annual 'Career opportunities in UK dentistry' event will take place on Friday 6 February 2009. Now its in ninth year, the BDA have once again teamed up with the UCL Eastman Dental Institute to produce this inspirational, informative event.

This is a great opportunity for vocational dental practitioners, young dentists, those returning to dentistry after a break and dentists from overseas to find out what exciting 
career options are available. The experienced programme of speakers will share their insights and knowledge on dentistry to help you make informed choices on your career path.

Employers of dentists and organisations who support dentists throughout their careers will also be exhibiting throughout the day. Venue and date:

Hotel Russell, London - 6 February 2009

\section{British Dental Conference}

\section{and Exhibition 2009}

The theme for the major dental event of 2009 is 'Securing your future; realising your potential' and will feature motivational, expert speakers who will inspire you to develop new ideas and grow your career.

The BDA are delighted that inspirational entrepreneur Charan Gill MBE, the man behind the leisure group Harlequin, will be the keynote speaker. Charan Gill landed in Glasgow at the age of nine, a bus conductor's son who barely spoke any English. By the age of 21 he began working in a friend's restaurant which he later came to manage. By the age of 30 Charan had bought a stake in the restaurant. Later he was to buy another restaurant across the street and by 2005 he owned 17 branches and had also diversified into property development. Charan is also known from his appearance on Channel 4's The secret millionaire. Charan Gill will encourage delegates to become inspired and to realise their potential in business.

The main clinical speaker at the 2009 event will be Dr Cherilyn Sheets from California, co-executive director of the Newport Coast Oral Facial Institute. She will be speaking on 'Meeting the demands of today's aesthetic restorative practice.'

There are many more speakers yet to be confirmed for the event. Keep an eye on the website www.bda.org/events for the latest developments and watch out for the conference brochure which will appear in January's edition of BDA News. Tickets for the British Dental Conference and Exhibition will go on sale on 5 January 2009 and exhibition stands will go on sale from 22 September 2008.

Venue and date:

SECC, Glasgow - 4-6 June 2009

***New MasterClass seminars - take your business skills to the next level**** If your ambition is to take your dental career to the next level, stand out from the crowd and aim high for your business, then you may have considered enrolling at the BDA's

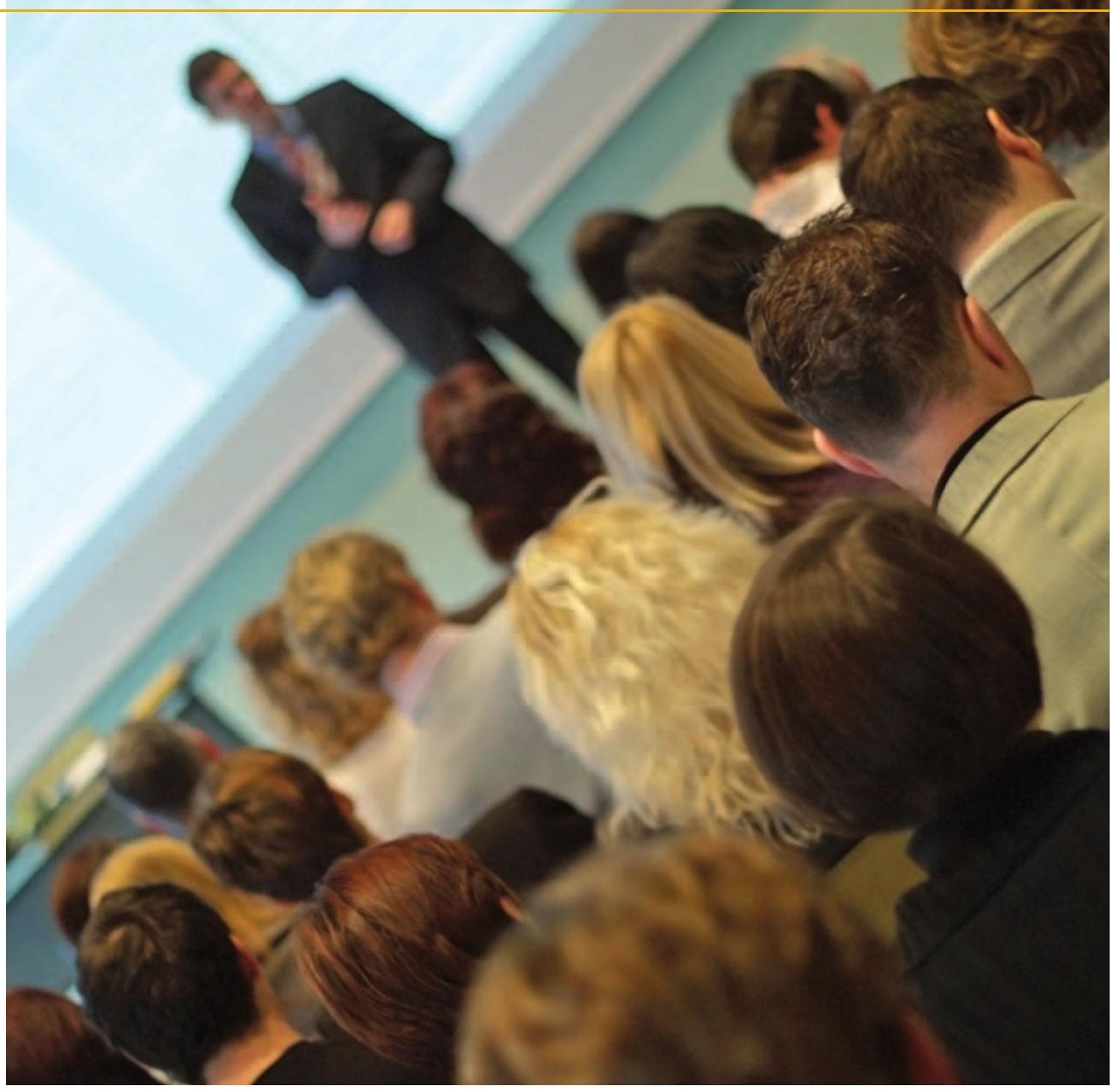

prestigious MasterClass business school. Delivered by the world-class Henley Business School, MasterClass is a management training course developed specifically for dentists. It consists of six days of tuition over a period of five weeks.

If you haven't yet decided whether to take the plunge and you want a taster of what it might be like to complete the MasterClass course, the BDA are running a series of seminars based on the MasterClass theme. These are stand-alone seminars which will provide delegates with practical skills and knowledge to put to work in the surgery straight away.

The seminars will cover:

- Developing a successful dental business - enhancing the patient experience, building a business plan and understanding the numbers

- Improving your communication skills in business situations - such as managing performance of staff, team motivation and negotiating with stakeholders.

The innovative course is to be delivered with the help of Henley's own speakers Steve Robinson and Nigel Spinks, and the pioneering theatre-skills business training company Interact. Steve Robinson is author of the Financial Times handbook of financial management and until recently was Director of the Advanced Management Programme and Head of Open Executive Programmes at Henley Business School. Nigel Spinks is a full-time member of the Schools Systems, Processes and Projects at Henley Business School, where he teaches process and operations management on Masters programmes. Interact are the UK's leading exponent of the use of theatre-skills in training and development. Interact produce highly experiential and interactive solutions and ensure that learning outcomes and communication messages come alive.

Courses are planned for November 2008 in London, March 2009 in Birmingham and July 2009 in Manchester. If you are interested in attending one of the courses then keep an eye on www.bda.org/events for confirmation of these details or call 02075634590 .

If you would like any more information on attending any of these events, please visit the BDA events website at www.bda. org/events or email the team on events@ bda.org. Organisations can also sponsor and exhibit at BDA events and this is a great way to meet and interact with dentists and members of the dental team. For more information on these opportunities please contact the BDA events team on events@bda.org. Tina Smith is Events Marketing and Sales Manger at the BDA. Contact t.smith@bda.org. DOI: 10.1038/sj.bdj.2008.741 